\title{
Triterpenoids from Acacia ataxacantha DC: antimicrobial and antioxidant activities
}

\author{
Abdou Madjid O. Amoussa ${ }^{1,2}$, Latifou Lagnika ${ }^{1 *}$, Mélanie Bourjot ${ }^{2}$, Cathérine Vonthron-Senecheau ${ }^{2}$ \\ and Ambaliou Sanni ${ }^{1}$
}

\begin{abstract}
Background: Acacia ataxacantha is a medicinal specie used extensively in traditional medicine of Benin republic to treat infectious diseases. Our previous study showed interesting antibacterial and antifungal activities against six strains of bacteria and six strains of fungi. The aim of this study was to investigate the antimicrobial and antioxidant activities of compounds isolated from $A$. ataxacantha.

Methods: Chromatographic and spectroscopic methods were used to isolate and identify three compounds (1-3) from the bark of $A$. ataxacantha. Phytochemical investigation of $A$. ataxacantha (Fabaceae) led to the isolation of three triterpenoids (1-3). The structure of isolated compounds was established by differents spectroscopic methods such as UV, ${ }^{1} \mathrm{H}$ NMR, ${ }^{13} \mathrm{C}$ NMR, 2D NMR and Mass. All isolated compounds were tested for antimicrobial activity using agar disc-diffusion and microdilution methods. The radical scavenging activity of isolated compounds was assessed using 2,2-diphenyl-1-picrylhydrazyl (DPPH) method.
\end{abstract}

Results: Phytochemical investigation led to the isolation and identification of lupeol (1), betulinic acid (2) and betulinic acid-3-trans-caffeate (3). Moderate antimicrobial activity was obtained with compound 3 against methicillin-resitant Staphylococcus aureus, Enterococcus feacalis and Pseudomonas aeruginosa with MIC value of $25 \mu \mathrm{g} / \mathrm{ml}$ and Staphylococcus aureus (MIC of $50 \mu \mathrm{g} / \mathrm{ml}$ ). Compounds 3 was more active against Staphylococcus epidermidis and Candida albicans with a MIC value of $12.5 \mu \mathrm{g} / \mathrm{ml}$ in boths cases. Compounds 3 had also interesting antioxidant activity with an $\mathrm{IC}_{50}$ of $3.57 \mu \mathrm{g} / \mathrm{ml}$ compared to quercetin $(1.04 \mu \mathrm{g} / \mathrm{ml})$.

Conclusion: The overall results of this study provide evidence that the compound 3, isolated from A. ataxacantha, exhibit antimicrobial activity against Gram-positive and Gram-negative bacteria and yeast, especially against $C$. albicans.

Keywords: Acacia ataxacantha, Triterpene, Betulinic acid-3-trans-caffeate, Antibacterial, Antifungal, Antioxidant

\section{Background}

Fabaceae, also known as Leguminosae represented by 730 genera like Stylosanthes, Tamarindus, Caesalpinia, Acacia and over 19400 species [1]. Acacia is a cosmopolitan genus containing in excess 1200 species and the highest density and the greatest diversity is found in tropical and subtropical regions, but also found throughout the world [2]. The aerial parts of different species of the genus Acacia are widely used in folk medicine due to their content of a variety of bioactive components

\footnotetext{
*Correspondence: llagnika@gmail.com

${ }^{1}$ Unité de Biochimie et Biologie Moléculaire, Equipe de Biochimie et Substances Naturelles Bioactives, Faculté des Sciences et Techniques, Université d'Abomey-Calavi, Cotonou 04 BP 0320, Bénin

Full list of author information is available at the end of the article
}

which are responsible for numerous pharmacological properties such as hypoglycemic, anti-inflammatory, antibacterial, antihypertensive, analgesic, anticancer and antiatherosclerotic [3]. Acacia ataxacantha is widespread in much of sub-Saharan Africa. This species is a very thorny shrub with the height of 5 to $8 \mathrm{~m}$. The leaves are alternate, with spine that carries 5 to 12 pairs of pinnae. On twigs, spines are short, clearly pointing down. The fruit pods are flattened, brownish red in the dry state. This specie has been reported in Benin, Nigerian and Kenya for its use in traditional medicine for the treatment of tooth decay, dysentery, bronchitis, cough and joint pain [4-6]. To the best of our knowledge, little phytochemical work has yet been done on $A$. ataxacantha. In a previous work, we 
reported the antioxidant, antifungal, antibacterial activities and toxicity of the bark extracts of this plant [7-9]. These results suggests that this plant might contain bioactive compounds that act as antimicrobial and antioxidant agents. It has been reported that in vitro tests do not necessarily confirm that the plant extracts are effective drugs or a suitable candidate for drug development, it provides a basis for understanding the effectiveness of the plant and leads in particular to the search for new active substances [10]. Therefore, the aim of this study was to isolate bioactive compound from $A$. ataxacantha barks and investigate their antimicrobial and antioxidant activities.

\section{Methods}

\section{Plant material}

Acacia ataxacantha barks were obtained from Ouidah, department of atlantic, South Bénin. Specimens were authenticated by Dr. Yedomohan, Botanist from National Herbarium of University of Abomey-Calavi. Voucher specimen (AA 6509/ HNB) have been deposited at the same Herbarium. The collected material was dried for four weeks in laboratory $\left(22^{\circ} \mathrm{C}\right)$, grinded into fine powder, and subjected to extraction.

\section{Extraction and isolation}

Dry powdered bark of $A$. ataxacantha (250 g) was successively extracted three times $(3 \times 500 \mathrm{ml})$ for $72 \mathrm{~h}$ with hexane, dichloromethane, ethyl acetate and methanol by maceration at room temperature. The resulting extracts were filtered, concentrated under reduced pressure, and kept at $4{ }^{\circ} \mathrm{C}$. The dichloromethane extract $(2.5 \mathrm{~g})$ was chromatographed by gradient elution on an open column (Silica gel Si 60, 0.063-0.200, mesh) using the mixture n-hexane/EtOAc and EtOAc-MeOH in increasing polarity to yield 36 fractions. These fractions were assembled into four fractions (A, B, C and D) according to the chromatographic profile obtained after thin layer chromatography (TLC) analysis. Fractions A (450 mg) and B (250 mg), soluble in dichloromethane, were recrystallized with methanol. The white precipitates obtained were purified by successive washing with methanol to obtain respectively compound $\mathbf{1}(25 \mathrm{mg})$ and 2 (32 mg). Purification of fraction $C$ was done using preparative HPLC (Gilson VP 250/21, Nucleodur 100-5 $\mathrm{C}_{18} \mathrm{ec}$, Macherey-Nagel, UV detection 220 and $254 \mathrm{~nm}$ ) with a gradient elution 10:90 to $90: 10$ (solvent A: $\mathrm{H}_{2} \mathrm{O}+0.1$ trifluoroacetic acid (TFA), B: $\mathrm{AcN}+0.1$ TFA) to obtain $7 \mathrm{mg}$ of compound 3 .

\section{Chemical elucidation of compounds}

Structural determination of the isolated compounds was carried out by spectrophotometric methods (1D and 2D NMR, mass and UV spectrometry). $1 \mathrm{D}\left({ }^{1} \mathrm{H},{ }^{13} \mathrm{C}\right)$ and $2 \mathrm{D}$ (COSY, NOESY, HSQC and HMBC) NMR spectrum were recorded at room temperature with a Bruker NMR spectrometer $(400 \mathrm{MHz}$ and $500 \mathrm{MHz}$ ), and mass spectra were recorded using LC-ESI-MS.

\section{Microbial strains}

Bacterial cultures used in this study included Staphylococcus aureus (ATCC 6538), Staphylococcus epidermidis (CIP 8039), Enterococcus faecalis (ATCC 29212), MethicillinResistant Staphylococcus aureus and Pseudomonas aeruginosa (CIP 82118), obtained from Laboratoire de Biophotonique et Pharmacologie, University of Strasbourg, France. Candida albicans (CIP 4872) culture used in the present study was obtained from national laboratory of drug control in Cotonou (Bénin). Bacterial were maintained on Mueller-Hinton agar (MHA) and yeast on Sabouraud Dextrose Agar (SDA) at $4{ }^{\circ} \mathrm{C}$. Sub-culturing was done weekly. The cells were inoculated in $\mathrm{MH}$ broth for bacteria $\left(37^{\circ} \mathrm{C}, 18 \mathrm{~h}\right)$ or $\mathrm{SD}$ broth for yeast $\left(30^{\circ} \mathrm{C}\right.$, $48 \mathrm{~h}$ ) prior to the test.

\section{Bioautography and identification of antimicrobial compounds}

This test was performed only on selected bacterial cultures which were remarkably inhibited by dichloromethane and ethyl acetate extracts, according to a modified version of the method of Srinivas et al., [11]. $10 \mu \mathrm{l}$ of the extracts $(20 \mathrm{mg} / \mathrm{ml})$ were applied on a chromatographic plate (Pre-coated TLC-sheets ALUGRAM ${ }^{\circledast}$ silica gel 60 with fluorescent indicator $\mathrm{UV}_{254}$; layer thickness $0.20 \mathrm{~mm}$ for analytical TLC) followed by elution with a mixture of dichloromethane/methanol (98:2) and dried in air. The plates were run in duplicate. The first plate was used as the reference chromatogram. The spots in the chromatogram were visualized in UV chamber (wavelength 365 and $254 \mathrm{~nm}$ ) and the plate was sprayed with sulfuric vanillin reagent. Other plates were used for the bioautography. The chromatograms were sprayed with bacterial culture $\left(10^{6} \mathrm{CFU} / \mathrm{ml}\right)$ of S. aureus, Methicillin-resistant S. Aureus, S. epidermidis, E. faecalis, $P$. aeruginosa and fungi culture $\left(2 \times 10^{5} \mathrm{CFU} / \mathrm{ml}\right)$ of $C$. albicans. Each plate was incubated at $\left(37^{\circ} \mathrm{C}, 24 \mathrm{~h}\right)$ for bacteria and $\left(30{ }^{\circ} \mathrm{C}, 48 \mathrm{~h}\right)$ for yeast. The inhibition zones were visualized by spraying the plates with $p$-iodonitrotetrazolium (INT, $2.0 \mathrm{mg} / \mathrm{ml}$ ).

\section{Disc diffusion assay}

The experiment was performed according to the method described by Qaralleh et al [12] with some modifications. For the determination of antimicrobial activity, cultures were adjusted to $10^{6} \mathrm{CFU} / \mathrm{ml}$ for bacteria and $2 \times 10^{5} \mathrm{CFU} / \mathrm{ml}$ for yeast using $0.5 \mathrm{McF}$ arland standards. Subsequently, cultures were inoculated into MHA for bacteria or SDA for yeast by spreading. The stock solutions of tested compounds were prepared by solubilizing $1 \mathrm{mg}$ of compound in $50 \mu \mathrm{l}$ of dimethyl 
sulfoxide $2.5 \%$ (DMSO $2.5 \%$ ). Then, these solutions were diluted in $950 \mu$ l of Mueller-Hinton broth for bacteria and Sabouraud broth for yeast strain to obtain $1 \mathrm{mg} / \mathrm{ml}$. The sterile discs of $6 \mathrm{~mm}$ of diameter were impregnated with $100 \mu \mathrm{g}(50 \mu \mathrm{l}, 2 \mathrm{mg} / \mathrm{ml})$ of each compound. Discs of gentamicin $(30 \mu \mathrm{g})$ and fluconazole $(25 \mu \mathrm{g})$ were used as standard antibacterial and antifungal controls respectively. The plates were incubated at $37{ }^{\circ} \mathrm{C}, 24 \mathrm{~h}$ for bacteria and $30{ }^{\circ} \mathrm{C}, 48 \mathrm{~h}$ for yeast. The diameters of inhibitory zones (including the diameter of the discs) were measured after the incubation period and values superior to $7 \mathrm{~mm}$ (D $7 \mathrm{~mm}$ ) were considered as active against microorganisms. All experiments were performed in triplicate and the antimicrobial activity was expressed as the mean of inhibition zone diameters.

\section{Minimum inhibitory concentration}

The two-fold serial microdilution method was used to determine the minimum inhibitory concentration (MIC) values of isolated compounds against microorganisms [9]. $100 \mu \mathrm{l}$ of isolated compound $(100 \mu \mathrm{g} / \mathrm{ml})$ and $50 \mu \mathrm{g} /$ $\mathrm{ml}$ of antimicrobial standards (Gentamicin, Fluconazol) were serially diluted two-fold in triplicate with MuellerHinton broth for antibacterial test and Sabouraud broth for yeast test in 96-well microplates to make eight concentrations of isolated compound $(0.78-100 \mu \mathrm{g} / \mathrm{ml})$ and standards $(0.39-50 \mu \mathrm{g} / \mathrm{ml}) .100 \mu \mathrm{l}$ of fresh culture of bacteria $\left(10^{6} \mathrm{CFU} / \mathrm{ml}\right)$ and yeast $\left(2 \times 10^{5} \mathrm{CFU} / \mathrm{ml}\right)$ were added to each well. DMSO (2.5\%) was used as negative control while gentamicin and fluconazole were used as positive controls.

\section{Minimum bactericidal and fungicidal concentration}

The minimum bactericidal (MBC) and minimum fungicidal concentration (MFC) of isolated compounds was determined according to the method of Escalona-Arranz et al [13]. To determine the MBC and MFC, aliquots of $20 \mu \mathrm{l}$ from all dilutions not showing any growth of bacteria and yeast were inoculated on sterile MHA plates (for bacteria) and SDA (for yeast) by spreading using swab sticks. Inoculated plates were incubated at $37{ }^{\circ} \mathrm{C}$ for $24 \mathrm{~h}$ for all bacteria, while those with yeast were incubated at $30{ }^{\circ} \mathrm{C}$ for $48 \mathrm{~h}$. After incubation, the concentration at which there is no visible growth on the agar plate was recorded as the minimal bactericidal concentration (MBC) and minimal fungicidal concentration (MFC). The experiment was carried out in triplicate.

\section{Determination of MIC index}

The MIC index (MBC/MIC) was calculated for each isolated compound and positive control drug to determine whether a compound had bactericidal/fungicidal
$(\mathrm{MBC} / \mathrm{MIC} \leq 4)$ or bacteriostatic/fungistatic $(4<\mathrm{MBC} /$ $\mathrm{MIC}<32$ ) effect [14].

\section{In vitro antioxidant activity}

The isolated compounds (2 mg) and quercetin (control) were dissolved in $1 \mathrm{ml}$ of methanol HPLC-grade. Dilutions were performed to obtain a stock solution at $100 \mu \mathrm{g} / \mathrm{ml}$. The antioxidant activity of isolated compounds on the stable radical 2,2-diphenyl-1-picrylhydrazyl (DPPH) was determined by the method developed by Danielle and Lall [15], with slight modifications. In this method 96-well plates were used. The stock solution $(100 \mu \mathrm{l})$ of each isolated compound and quercetin was added separately to the wells in the top row. A two-fold serial dilutions was performed to obtain a concentration range from 1.56 to $100 \mu \mathrm{g} / \mathrm{ml}$. Finally, $200 \mu \mathrm{l}$ of methanolic solution of 2,2-diphenyl-1-picrylhydrazyl (2\%) were introduced in each well. The plates were allowed to develop in the dark for $30 \mathrm{~min}$ before the measurement of the absorbance at $517 \mathrm{~nm}$ using a Microplate Reader (Rayto-6500). The capability of each compound and the standard to scavenging the free radical was determined as inhibition percentage using the following formula:

Inhibition percentage $(\mathrm{I} \%)=\left[\left(\mathrm{A}_{\text {Blank }}-\mathrm{A}_{\text {sample }}\right) / \mathrm{A}_{\text {Blank }}\right] \times 100$

$\mathrm{A}_{\mathrm{Blank}}$ is the absorbance of the control reaction (containing all reagents except the test sample) $A_{\text {sample }}$ is the absorbance of sample/standard.

The concentration of compound reducing $50 \%$ of free radical DPPH $\left(\mathrm{IC}_{50}\right)$ was determined graphically. The assay was replicated three times and results are expressed as mean \pm standard deviation.

\section{Statiscal analysis}

All experiments were conducted in triplicate and the results were expressed as means \pm standard deviation. The graph was performed using the Graph Pad Prism 6.1 software (Microsoft, USA).

\section{Results and discussion}

\section{Phytochemical investigation}

The fractionation of the dichloromethane extract of $A$. ataxacantha using silica gel column chromatography led to the isolation of three compounds (1-3) identified as lupeol, betulinic acid and betulinic acid-3-trans-caffeate (Fig. 1).

Compound 1: White powder, ${ }^{1} \mathrm{H}$ NMR (400 MHz, $\left.\mathrm{CDCl}_{3}\right): \delta_{\mathrm{H}} 0.72(3 \mathrm{H}, \mathrm{s}, \mathrm{H}-24), 0.78(3 \mathrm{H}, \mathrm{s}, \mathrm{H}-28), 0.81$ (3H, s, H-25), 0.92 (3H, s, H-27), 0.97 (3H, s, H-23), 1.01 (3H, s, H-26), 1.66 (3H, s, H-30), 3.17 (1H, dd, $\mathrm{J}=11 \mathrm{~Hz}, 5 \mathrm{~Hz}, \mathrm{H}-3), 4.55(1 \mathrm{H}, \mathrm{dd}, \mathrm{J}=2.4 \mathrm{~Hz}, 1.4 \mathrm{~Hz}$, $\mathrm{H}-29 \alpha), 4.67(1 \mathrm{H}, \mathrm{d}, \mathrm{J}=2.4 \mathrm{~Hz}, \mathrm{H}-29 \beta)$. The ${ }^{1} \mathrm{H}$ 


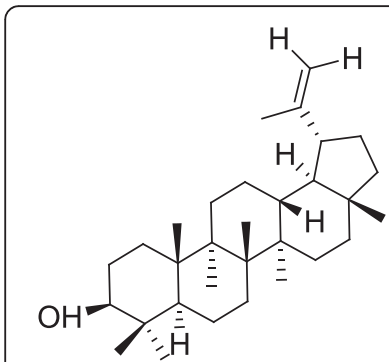

(1)

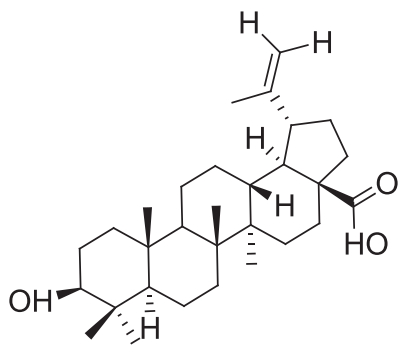

(2)

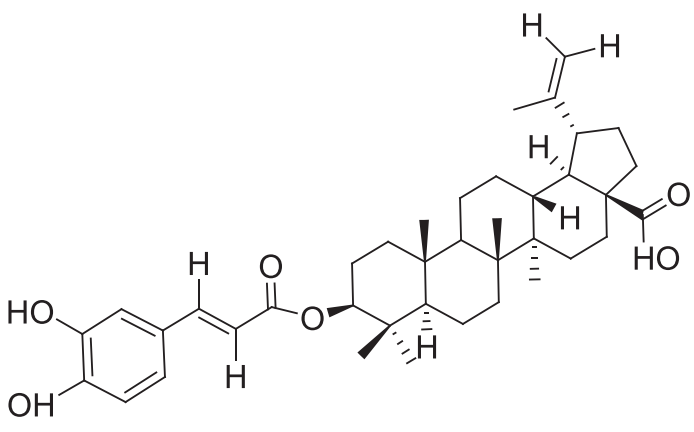

(3)

Fig. 1 Isolated triterpenes from Acacia ataxacantha. (1): lupeol; (2): Betulinic acid; (3): Betulinic acid-3-trans-caffeate

NMR spectrum of compound 1 revealed the presence of seven tertiary methyl protons at $\delta 0.72,0.78,0.81$, $0.92,0.97,1.01$ and 1.66 (integrated for $3 \mathrm{H}$ - each). A sextet of one proton at $\delta 2.37$ assign to $19 \beta-\mathrm{H}$ is characteristic of lupeol. The $\mathrm{H}-3$ proton showed a split doublet at $\delta 3.17$ with a coupling constant of $11 \mathrm{~Hz}$ and $5 \mathrm{~Hz}$ while, a pair of doublet at $\delta 4.55$ and $\delta 4.67$ $(1 \mathrm{H}$, each) was indicative of olefinic protons at $(\mathrm{H}-29$ a \& b). Compound 1 was identified as lupeol. All spectral data were in agreement with literature [16-18].

Compound 2: White powder, ${ }^{1} \mathrm{H}$ NMR $(400 \mathrm{MHz}$, $\left.\mathrm{CDCl}_{3}\right): \delta_{\mathrm{H}} 0.65(3 \mathrm{H}, \mathrm{s}, \mathrm{H}-24), 0.76(3 \mathrm{H}, \mathrm{s}, \mathrm{H}-25)$, 0.86 (3H, s, H-26), 0.93 (3H, s, H-23), 0.97 (3H, s, H-27), 1.65 (3H, s, H-30), 3.32 (1H, m, H-3), 4.56 $(1 \mathrm{H}, \mathrm{s}, \mathrm{H}-29 \alpha)$. The ${ }^{1} \mathrm{H}-\mathrm{NMR}$ spectrum of compound 2 exhibited signals for methyl groups at $\delta$ $0.65,0.76,0.86$, and $0.93,0.97$ and 1.65 . The ${ }^{1} \mathrm{H}$ NMR spectrum also displayed signals for olefinic hydrogens at $\delta 4.69, \delta 4.56(2 \mathrm{H}, \mathrm{s})$ for $\mathrm{H}-29$ and hydrogen attached to carbon bearing $\mathrm{OH}(\mathrm{H}-3)$ at $\delta$ $3.32(1 \mathrm{H}, \mathrm{s})$, respectively. The spectral data of compounds 2 were in agreement with previously published data of betulinic acid [19, 20].

Compound 3: White amorphous powder. The molecular formula of 3 determined to be $\mathrm{C}_{39} \mathrm{H}_{54} \mathrm{O}_{6}$ by positive mode LC-ESI-MS data at $\mathrm{m} / \mathrm{z} 641.38035$ $[\mathrm{M}+\mathrm{Na}]^{+}$(calcd for $\mathrm{C}_{39} \mathrm{H}_{54} \mathrm{O}_{6}, 641.38035$ ). The UV spectrum exhibited absorption maxima at 245 and $320 \mathrm{~nm}$, suggesting the presence of an aromatic ring
Table 1 NMR Spectroscopic Data (500 MHz, CDCl $)$ of compound 3 (betulinic acid-3-trans-caffeate)

\begin{tabular}{|c|c|c|}
\hline \multirow[t]{2}{*}{ Position } & \multicolumn{2}{|l|}{ Compound 3} \\
\hline & $\delta_{H}(J$ in $\mathrm{Hz})$ & $\delta_{C,}$ type \\
\hline 1 & $1.73(\mathrm{~m}), 1.07(\mathrm{~m})$ & $39.2, \mathrm{CH}_{2}$ \\
\hline 2 & $1.68(\mathrm{~m}), 1.68(\mathrm{~m})$ & 24.6, $\mathrm{CH}_{2}$ \\
\hline 3 & $4.57(t, 5.1)$ & $81.2, \mathrm{CH}$ \\
\hline 4 & - & $38.3, \mathrm{C}$ \\
\hline 5 & $0.91(\mathrm{~m})$ & 55.7, $\mathrm{CH}$ \\
\hline 6 & $1.53(\mathrm{~m}), 1.46(\mathrm{~m})$ & $19, \mathrm{CH}_{2}$ \\
\hline 7 & $1.39(\mathrm{~m}), 1.51(\mathrm{~m})$ & 35.1, $\mathrm{CH}_{2}$ \\
\hline 8 & - & 42.7, C \\
\hline 9 & $1.43(\mathrm{~m})$ & $50.7, \mathrm{CH}$ \\
\hline 10 & - & $34.6, \mathrm{C}$ \\
\hline 11 & $1.12(\mathrm{~m}), 1.46(\mathrm{~m})$ & 21.8, $\mathrm{CH}_{2}$ \\
\hline 12 & $1.26(\mathrm{~m}), 1.74(\mathrm{~m})$ & 26.4, $\mathrm{CH}_{2}$ \\
\hline 13 & $2.39(\mathrm{~m})$ & 39.0, $\mathrm{CH}$ \\
\hline 14 & - & 43.3, C \\
\hline 15 & $1.59(\mathrm{~m}), 1.20(\mathrm{~m})$ & $30.5, \mathrm{CH}_{2}$ \\
\hline 16 & $2.26(\mathrm{~m}) 1.44(\mathrm{~m})$ & 32.9, $\mathrm{CH}_{2}$ \\
\hline 17 & - & $56.8, C$ \\
\hline 18 & $1.59(\mathrm{~m})$ & 49.5, CH \\
\hline 19 & $3.0(\mathrm{~m})$ & 47.1, $\mathrm{CH}$ \\
\hline 20 & - & $150, C$ \\
\hline 21 & $1.93(\mathrm{~m}), 1.37(\mathrm{~m})$ & 31.4, $\mathrm{CH}_{2}$ \\
\hline 22 & $1.50(\mathrm{~m}), 1.92(\mathrm{~m})$ & $37.9, \mathrm{CH}_{2}$ \\
\hline 23 & $0.86(\mathrm{~s})$ & 28.3, $\mathrm{CH}_{3}$ \\
\hline 24 & $0.89(\mathrm{~s})$ & $16.3, \mathrm{CH}_{3}$ \\
\hline 25 & $0.93(\mathrm{~s})$ & 16.9, $\mathrm{CH}_{3}$ \\
\hline 26 & $0.97(\mathrm{~s})$ & $16.4, \mathrm{CH}_{3}$ \\
\hline 27 & $0.97(\mathrm{~s})$ & 14.9, $\mathrm{CH}_{3}$ \\
\hline 28 & - & 177.8, C \\
\hline 29 & $4.60,4.57$ (brs) & $110, \mathrm{CH}_{2}$ \\
\hline 30 & $1.68(\mathrm{~s})$ & 19.6, $\mathrm{CH}_{3}$ \\
\hline $1^{\prime}$ & - & $128, C$ \\
\hline $2^{\prime}$ & $7.07(d, 1.2)$ & 122.6, $\mathrm{CH}$ \\
\hline $3^{\prime}$ & - & 115.8, C \\
\hline $4^{\prime}$ & - & $146.1, C$ \\
\hline $5^{\prime}$ & $6.86(d, 8.0)$ & 143.9, $\mathrm{CH}$ \\
\hline $6^{\prime}$ & $6.99(\mathrm{dd}, 8.0,1.2)$ & 114.6, CH \\
\hline $7^{\prime}$ & $7.53(\mathrm{~d}, 15.9)$ & 144.3, $\mathrm{CH}$ \\
\hline $8^{\prime}$ & $6.24(d, 15.9)$ & 116.9, CH \\
\hline $9^{\prime}$ & - & 167.7, C \\
\hline
\end{tabular}

Assignments were based on 2D NMR including HSQC, HMBC and NOESY. Well-resolved couplings are expressed with coupling patterns and coupling constants in hertz in parentheses 
in the molecule. ${ }^{1} \mathrm{H}$ and ${ }^{13} \mathrm{C}$ NMR spectral data were resumed in Table 1 . The $2 \mathrm{D}$ experiments (COSY, NOESY, HSQC and HMBC) were performed using standard Bruker programs.

The compound 3 was inferred to be a triterpene, based on the ${ }^{1} \mathrm{H}$ NMR spectrum with a broad range of aliphatic signals including six methyl singlets and the ${ }^{13} \mathrm{C}$ NMR spectrum with 30 carbons (Table 1). Further investigation of ${ }^{13} \mathrm{C}$ NMR spectrum revealed the characteristic signals for carboxylic acid $\left(\delta_{\mathrm{C}}\right.$ 177.8), vinyl carbons (quaternary $\mathrm{C}$ at $\delta_{\mathrm{C}} 150.0$ and $\mathrm{CH}_{2}$ at $\delta_{\mathrm{C}}$ $110.0)$ as well as an oxygen-bearing methine $\left(\delta_{C} 81.2\right)$. This information suggested that the compound $\mathbf{3}$ is a derivative of betulinic acid bearing an additional aromatic ester moiety at $\mathrm{C}-3$. The aromatic ester was identfied as caffeate by ${ }^{1} \mathrm{H}$ NMR displaying trans olefin signal at $\delta 6.24(\mathrm{~d}, J=15.9 \mathrm{~Hz})$. The compound 3 was identified as betulinic acid-3-trans-caffeate, which was confirmed by comparing its data to literature values [21-23].

\section{Antimicrobial activity}

The bioautography technique has been used to identify the bioactive constituents from $A$. ataxacantha extracts. Inhibition zones of antimicrobial components were observed as white spots on a purple red background (Fig. 2). These white areas indicate the presence of antimicrobial compounds which inhibit the growth of microorganisms which did not support the reduction of INT to the coloured formazan [24]. In a previous study, dichloromethane (DCM) extract demonstrated the lowest MIC against $S$. aureus, methicillin-resistent $S$. aureus,
S. epidermidis, E. faecalis and P. aeruginosa [9]. Hence, these bacteria were selected for the bioautography assay to identify antimicrobial compounds. The bioautography assay exhibited inhibition zones (Rf 0.59) for dichloromethane extract against both Gram positive (S. aureus, methicillin-resistent $S$. aureus, S. epidermidis and $E$. faecalis) and Gram negative (P. aeruginosa) (Fig. 2). Interestingly, the bioautogram with $C$. albicans showed inhibition zones at Rf 0.59 (Fig. 3) indicating the same compound was responsible for the antifungal activity against $C$. albicans.

Subsequently, an experiment was conducted to isolate and identify the actives compounds. The isolated compounds were investigated for their antimicrobial activity against Gram-positive ( $S$. aureus, methicillin-resistent $S$. aureus, S. epidermidis and E. faecalis), Gram-negative $(P$. aeruginosa) and yeast ( $C$. albicans). The results obtained with disc diffusion assay were presented in Table 2. Only Compound $\mathbf{3}$ out of the isolated compounds was active against all tested microorganisms (Table 2). The diameter of inhibition of compound 3 ranged from 15.7 to $23.3 \mathrm{~mm}$. The highest inhibitory effect was observed against $S$. epidermidis with inhibition diameter of $23.3 \mathrm{~mm}$. Overall, the Gram-positive bacteria showed a greater susceptibility to compound 3 while $P$. aeruginosa (Gram-negative) showed moderate sensitivity. Compounds $\mathbf{1}$ and $\mathbf{2}$ did not inhibit the growth of microorganisms at $100 \mu \mathrm{g} /$ disc. Previous study showed that compounds $\mathbf{1}$ and $\mathbf{2}$ were active against Escherichia Coli, Bacillus Subtilis and Staphylococcus aureus with MIC values ranged from 100 to $200 \mu \mathrm{g} / \mathrm{ml}$ [25]. The negligible antimicrobial activity of compounds 1 and 2 could be explained by the concentration used.

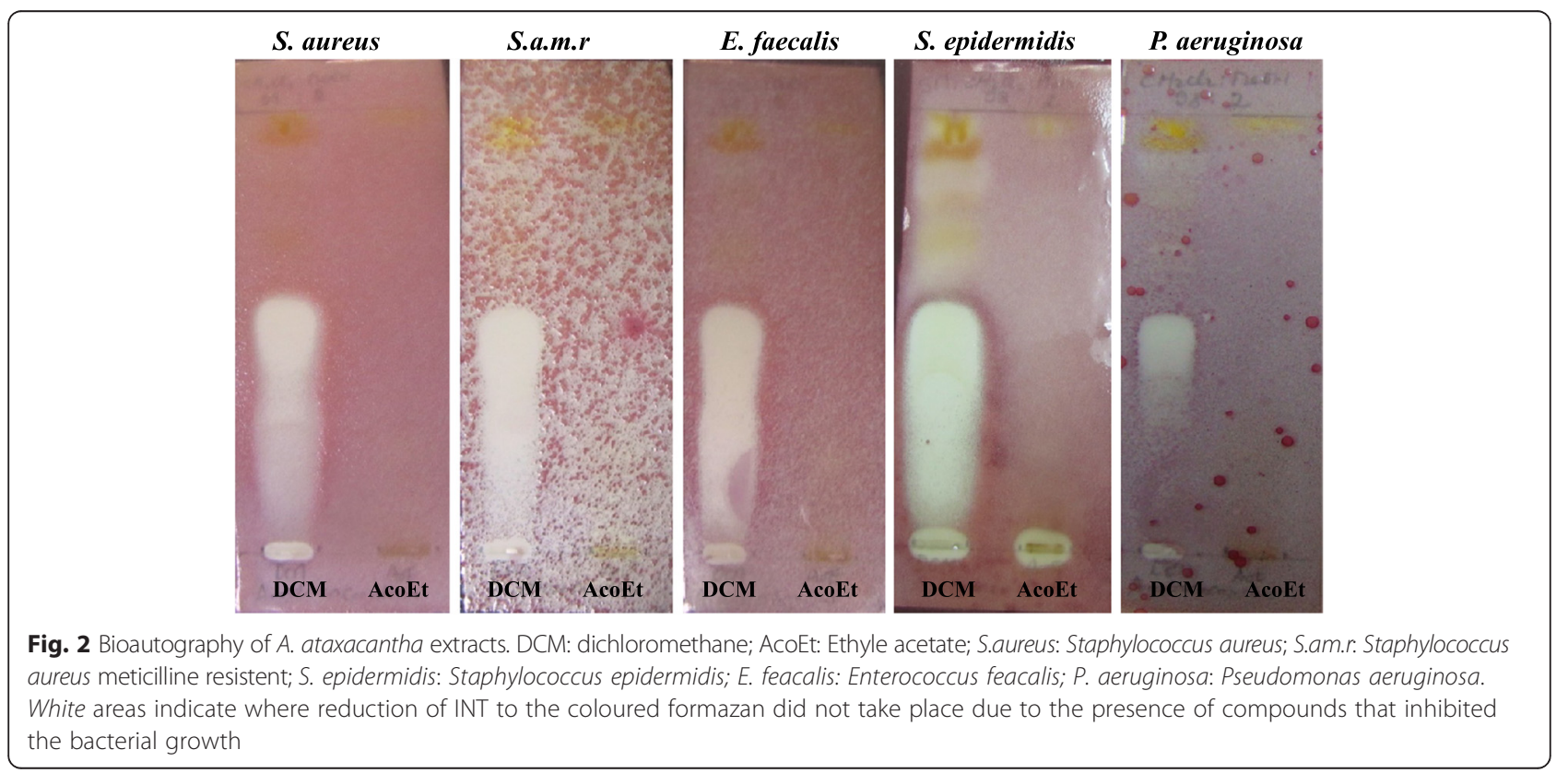




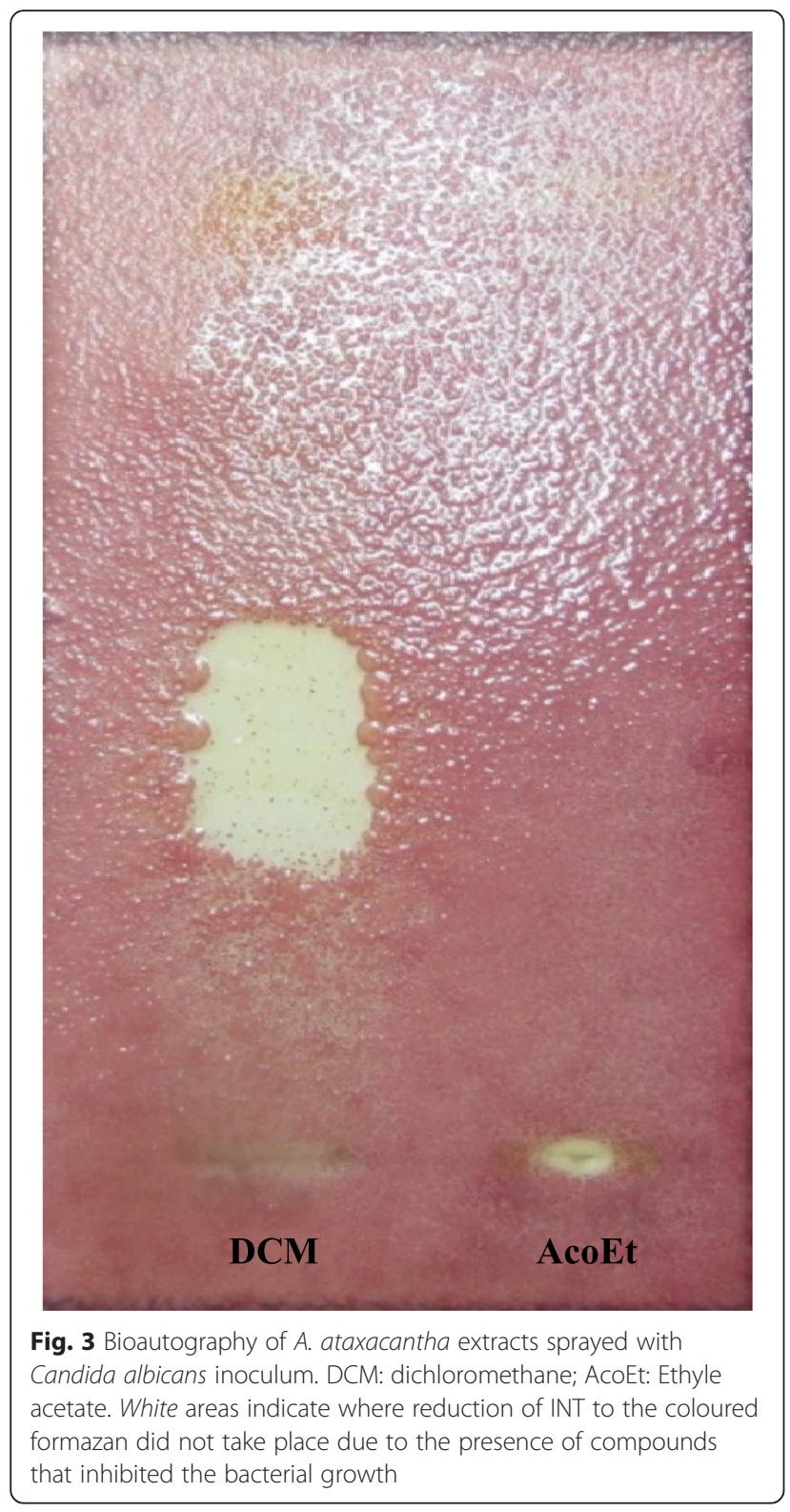

However, it was reported that betulinic acid was not active against the Gram-positive, Gram-negative bacteria and yeast [26].

The present study has also assessed the quantitative antimicrobial activity of isolated compounds by determining their MIC, MBC and MFC. The results were reported in Table 3. Many reports consider the antimicrobial activities of compounds to be significant if the MIC is $10 \mu \mathrm{g} /$ $\mathrm{ml}$ or lower, moderate if $10<\mathrm{MIC} \leq 100 \mu \mathrm{g} / \mathrm{ml}$ and low if MIC $>100 \mu \mathrm{g} / \mathrm{ml}[27,28]$. Referring to these criteria, the tested compounds had moderate antimicrobial activity with MICs ranged from 12.5 to $50 \mu \mathrm{g} / \mathrm{ml}$. MBC and MFC values varied between 25 to $50 \mu \mathrm{g} / \mathrm{ml}$. Only compound 3 showed antimicrobial activity against tested microorganisms at different level. This compound was active against $S$. aureus and $P$. aeruginosa (MIC and $\mathrm{MBC}$ were $25 \mu \mathrm{g} / \mathrm{ml}$ in both cases), methicillin-resitant $S$. aureus and E. faecalis (MIC or MBC were $50 \mu \mathrm{g} / \mathrm{ml}$ in both cases). The lowest MIC $(12.5 \mu \mathrm{g} / \mathrm{ml})$ of compound 3 was recorded against $S$. epidermidis with a $\mathrm{MBC}$ value of $25 \mu \mathrm{g} / \mathrm{ml}$. Aba et al., also demonstrated the antimicrobial activity of the amyrenol, a triterpene isolated from the roots of $A$. ataxacantha with MIC value of $12 \mu \mathrm{g} / \mathrm{ml}$ and MBC/MFC of $25 \mu \mathrm{g} / \mathrm{ml}$ against Bacillus subtilis, Escherichia coli and Salmonella typhi [29]. Our results and those obtained by Aba et al, demonstrated the importance of triterpenes in the antimicrobial activity of A. ataxacantha.

The mechanism of antibiosis of the compound 3 was calculated using MIC index as described by Stefanovic and Comic [14], to elucidate whether the observed antibacterial effect was bactericidal or bacteriostatic. Higher values of MBC and MFC than those of MIC indicates the bacteriostatic or fungistatic nature of the compound 3 against methicillin-resistant S. aureus, $S$. epidermidis, E. faecalis and C. albicans. The same values of $\mathrm{MBC}$ and $\mathrm{MIC}$ observed against $S$. aureus $(50 \mu \mathrm{g} / \mathrm{ml})$ and $P$. aeruginosa $(25 \mu \mathrm{g} / \mathrm{ml})$ indicated the bactericidal nature of compound 3. MIC and MBC values of compound $\mathbf{3}$ were most interesting against $P$. aeruginosa which is a Gram-negative bacterium.

Table 2 Preliminary antimicrobial testing of isolated compounds (1-3) by determination the zone of inhibitory ( $\mathrm{mm}$ )

\begin{tabular}{|c|c|c|c|c|c|}
\hline Bacteria/Fungus & $1\left(100 \mu \mathrm{g} \cdot \mathrm{disc}^{-1}\right)$ & $2\left(100 \mu \mathrm{g} \cdot \mathrm{disc}^{-1}\right)$ & $3\left(100 \mu \mathrm{g} \cdot \mathrm{disc}^{-1}\right)$ & $\operatorname{Gentamicin}\left(30 \mu \mathrm{g} \cdot \operatorname{disc}^{-1}\right)$ & Fluconazole $\left(25 \mu \mathrm{g} \cdot \operatorname{disc}^{-1}\right)$ \\
\hline S. $a$ & NA & NA & $18.3 \pm 0.1$ & $22.5 \pm 0.0$ & $\mathrm{Nt}$ \\
\hline S.a.m.r & NA & NA & $20.0 \pm 0.1$ & $18.5 \pm 0.0$ & $\mathrm{Nt}$ \\
\hline S.ep & NA & NA & $23.3 \pm 0.0$ & $20.5 \pm 0.0$ & $\mathrm{Nt}$ \\
\hline E. $f$ & NA & NA & $21.0 \pm 0.1$ & $22.0 \pm 0.0$ & $\mathrm{Nt}$ \\
\hline P. a & NA & NA & $15.3 \pm 0.0$ & $14.0 \pm 0.1$ & $\mathrm{Nt}$ \\
\hline C. $a$ & NA & NA & $15.7 \pm 0.0$ & NT & $13.7 \pm 0.1$ \\
\hline
\end{tabular}

Each value is expressed as means $(n=3) \pm$ standard deviation (SD)

S.a :Staphylococcus aureus;Samr: Staphylococcus aureus methicillin resistant; S.ep :Staphylococcus epidermidis; E.f: Enterococcus faecalis; P. a: Pseudomonas aeruginosa; C. a: Candida albicans. 1: lupeol; 2: betulinic acid; 3: betulinic acid-3-trans-caffeate. NA: not actif; NT: not tested 
Table 3 Minimum inhibitory concentration (MIC) and Minimum bactericidal and fungicidal concentrations (MBC, MFC) of compound 3 from $A$. ataxacantha

\begin{tabular}{|c|c|c|c|c|c|c|}
\hline \multicolumn{7}{|c|}{ Minimum inhibitory concentrations $(\mu \mathrm{g} / \mathrm{ml})$} \\
\hline \multirow[t]{2}{*}{ Microorganisms $^{a}$} & \multicolumn{4}{|c|}{ Gram (+) bacteria } & \multirow{2}{*}{$\begin{array}{l}\text { Gram (-) bacteria } \\
\text { P. a }\end{array}$} & \multirow{2}{*}{$\begin{array}{l}\text { Yeast } \\
\text { C. } a\end{array}$} \\
\hline & S. $a$ & S.a.m.r & S. ep & E.f & & \\
\hline $3^{b}$ & 50 & 25 & 12.5 & 25 & 25 & 12.5 \\
\hline Gentamicin & 0.39 & 0.39 & 0.78 & 0.39 & 0.78 & $\mathrm{Nt}$ \\
\hline Fluconazole & $\mathrm{Nt}$ & $\mathrm{Nt}$ & $\mathrm{Nt}$ & $\mathrm{Nt}$ & $\mathrm{Nt}$ & 0.78 \\
\hline \multicolumn{7}{|c|}{ Minimum bactericidal and fungicidal $(\mu \mathrm{g} / \mathrm{ml})$} \\
\hline $3^{b}$ & 50 & 50 & 50 & 50 & 25 & 25 \\
\hline Gentamicin & 0.78 & 1.56 & 1.56 & 0.78 & 1.56 & $\mathrm{Nt}$ \\
\hline Fluconazole & $\mathrm{Nt}$ & $\mathrm{Nt}$ & $\mathrm{Nt}$ & $\mathrm{Nt}$ & $\mathrm{Nt}$ & 1.56 \\
\hline \multicolumn{7}{|c|}{ MIC index } \\
\hline $3^{b}$ & 1 & 2 & 4 & 2 & 1 & 2 \\
\hline Gentamicin & 2 & 4 & 2 & 2 & 2 & $\mathrm{Nt}$ \\
\hline Fluconazole & $\mathrm{Nt}$ & $\mathrm{Nt}$ & $\mathrm{Nt}$ & $\mathrm{Nt}$ & $\mathrm{Nt}$ & 2 \\
\hline
\end{tabular}

${ }^{a}$ S.a : Staphylococcus aureus; S.a.m.r : Staphylococcus aureus methicillin resitant; S.ep : Staphylococcus epidermidis; E.f: Enterococcus faecalis; P.a: Pseudomonas aeruginosa; C.a: Candida albicans

b: betulinic acid-3-trans-caffeate

Nt: not tested. MIC, MBC or MFC of compounds $\mathbf{1}$ and $\mathbf{2}$ were not determined

Several decades ago, the search for antimicrobials was still focused on the discovery of natural compounds able to inhibit Gram-negative bacteria, which are dangerous and causing infectious diseases. The Gramnegative cell wall (made up of lipopolysaccharide) is complex and multilayered structure, which makes access to membrane more restricted and barrier to many environmental substances including synthetic and natural antibiotics [30]. The results of this study indicate that the compound 3, isolated from the bark of $A$. ataxacantha, could be an agent able to cross this complex barrier. In this study, compound $\mathbf{3}$ (betulinic acid-3-trans-caffeate) is found more active than compound $\mathbf{2}$ (betulinic acid). This observation is in accordance with the structure-activity relationship as reported previously [20,31].

Table 4 Antioxidant activity of compounds (1-3) isolated from A. ataxacantha

\begin{tabular}{ll}
\hline Samples & $I C_{50}(\mu \mathrm{g} / \mathrm{ml})$ \\
\hline Compounds & \\
$\mathbf{1}$ & $16.77 \pm 0.18$ \\
$\mathbf{2}$ & $25.15 \pm 0.01$ \\
$\mathbf{3}$ & $3.57 \pm 0.02$ \\
Reference & \\
Qercetin & $1.04 \pm 0.01$
\end{tabular}

The value of $\mathrm{IC}_{50}$ are expressed as means $(n=3) \pm$ standard deviation (SD) 1: lupeol, 2: betulinic acid, 3: betulinic acid-3-trans-caffeate

\section{Antioxidant activity}

The antioxidant activity of isolated compounds (1-3) were determined using DPPH method and the results are reported in Table 4. Compounds 3 (betulinic acid-3trans-caffeate) had significant antioxidant activity with an $\mathrm{IC}_{50}$ of $3.57 \mu \mathrm{g} / \mathrm{ml}$ compared to quercetin (control) $1.04 \mu \mathrm{g} / \mathrm{ml}$. Compound 1 (lupeol) showed moderate activity with an $\mathrm{IC}_{50}$ value of $16.77 \mu \mathrm{g} / \mathrm{ml}$ while compound 2 (betulinic acid) had weak DPPH scavenging activity with an $\mathrm{IC}_{50}$ of $25.15 \mu \mathrm{g} / \mathrm{ml}$. The antioxidant activity of lupeol was previously reported [32, 33]. The interesting antioxidant activity of compound 3 could be attributed to the phenolic nature of the caffeate substituent. The antioxidant activity of Alkyl caffeates have been also reported [34].

\section{Conclusion}

The results of the present study showed that the betulinic acid-3-trans-caffeate isolated from the bark of $A$. ataxacantha possesses good antimicrobial and antioxidant potency. This compound could be a candidate for structure-activity study in the case of the development of novel antimicrobial agents with an improved therapeutic index. This is the first report on the presence of lupeol, betulinic acid and betulinic acid-3-trans-caffeate in this specie. Further studies are in progress to identify the synergy between the isolated compounds and standard antibiotics.

\section{Abbreviations}

1D, dimensional; 2D, two dimensional; ATCC, American Type Culture Collection; CFU, Colony-forming unit; CIP, collection institute Pasteur; COSY, Correlation Spectroscopy; DCM, dichloromethane; DMSO, Dimethyl sulfoxide; DPPH, 2,2diphenyl-1-picrylhydrazyl; EtoAc, ethyl acetate; HMBC, Heteronuclear Multiple Bond Correlation; HPLC, High performance liquid chromatography; HSQC, Heteronuclear single quantum coherence spectroscopy; INT, p-iodonitrotetrazolium; MBC, minimum bactericidal concentration; $\mathrm{MeOH}$, methanol; MFC, minimum fungicidal concentration; MHA, Mueller-Hinton agar; MIC, minimum inhibitory concentration; NMR, Nuclear magnetic resonance; NOESY, Nuclear Overhauser Effect Spectroscopy; SDA Sabouraud Dextrose Agar; TFA, trifluoroacetic acid; TLC, thin layer chromatography

\section{Acknowledgements}

We thank the International Foundation for Science (IFS) (Grant F / 5673-1) for supporting equipment and Wood-Wheland fellowship from International Union of Biochemistry and Molecular Biology (IUBMB) for the trip to Strasbourg.

\section{Funding}

This study was granted from International Foundation for Science (IFS) (Grant F/5673-1).

\section{Availability of data and material}

Data are all contained within the paper.

\section{Authors' contributions}

LL designed the study, followed the implementation, participated to isolate compounds, wrote the manuscript, AMA isolated compounds, carried out antimicrobial and antioxidant assay, MB and CVS carried out structural identification of isolated compounds and participated to write the manuscript, AS coordinate the team and helped to revise the manuscript. All authors read and approved the final manuscript. 


\section{Competing interests}

The authors declare that they have no competing interests.

\section{Consent for publication}

Not applicable.

\section{Ethics approval and consent to participate}

Not applicable.

\section{Author details}

'Unité de Biochimie et Biologie Moléculaire, Equipe de Biochimie et Substances Naturelles Bioactives, Faculté des Sciences et Techniques, Université d'Abomey-Calavi, Cotonou 04 BP 0320, Bénin. ²Laboratoire d'Innovation Thérapeutique, Faculté de Pharmacie, UMR CNRS-Unistra 7200 Illkirch, France.

Received: 16 January 2016 Accepted: 5 August 2016

Published online: 12 August 2016

\section{References}

1. Lalitha P, Sripathi SK, Jayanthi P. Acute toxicity study of extracts of Eichhornia Crassipes (Mart.) Solms. Asian J Pharm Clin Res. 2012:5(4):59-61.

2. Adamu M, Naidoo V, Eloff JN. Some southern African plant species used to treat helminth infections in ethnoveterinary medicine have excellent antifungal activities. BMC Complement Altern Med. 2012;12:213

3. Singh BN, Singh BR, Singh RI, Prakesh D, Dhakarey R, Upadhyay G, et al. Oxidative DNA Damage protective activity, antioxidant and antiquorum sensing potentiels of Moringa oleifera. Food Chem Toxicol. 2009:47:1109-16.

4. Adjanohoun I, Ahyi M, Aké A, Akouegninou A, Dalmeida J, Akpovo F, Bouke FK, et al. Contribution aux études ethnobotaniques et floristiques en République Populaire du Bénin. Paris: ACCA; 1989. p. 852

5. MacDonald I, Joseph OE, Harriet ME. Documentation of medicinal plants sold in markets in Abeokuta, Nigeria. Trop J Pharm Res. 2010;9(2):110-8.

6. Kereru PG, Kenji GM, Gachanga AN, Keriko JM, Mungai G. Traditional medicines among EMBU and Mbeere people of Kenya. Afr J CAM. 2007:4(1):75-86.

7. Amoussa AMO, Sanni A, Lagnika L. Antioxidant activity and total phenolic, flavonoid and flavonol contents of the bark extracts of Acacia ataxacantha. J Pharmacogn Phytochem. 2015;4(2):172-8.

8. Amoussa $\mathrm{AMO}$, Tchatchedre M, Laleye A, Sanni A, Lagnika L. Acute toxicity and antifungal effects of Acacia ataxacantha (Bark). Int J Pharmacogn Phytochem Res. 2015;7(4):661-8.

9. Amoussa $\mathrm{AMO}$, Lagnika L, Sanni A. Acacia ataxacantha (bark): chemical composition and antibacterial activity of the extracts. Int J Pharm Pharm Sci. 2014:6(11):138-41.

10. Olajuyigbe OO, Afolayan AJ. In vitro antibacterial and time-kill evaluation of the Erythrina caffra Thunb. extract against bacteria associated with diarrhoea. Sci World J. 2012;2012:8. doi:10.1100/2012/738314.

11. Srinivas $P$, Rajashekar V, Upender RE, Venkateshwarulu L, Anil KCH. Phytochemical screening and in vitro antimicrobial investigation of the methanolic extract of Xanthium strumarium leaf. Int J Drug Dev Res. 2011:3:286-93.

12. Qaralleh HN, Abboud MM, Khleifat KM, Tarawneh KA, Althunibat OY. Antibacterial activity in vitro of Thymus capitatus from Jordan. Pak J Pharm Sci. 2009;22(3):247-51.

13. Escalona-Arranz JC, Péres-Roses R, Urdaneta-Laffita I, Camacho-Pozo Ml, Rodríguez-Amado J, Licea-Jiménez I. Antimicrobial activity of extracts from Tamarindus indica L. leave. Pharmacogn Mag. 2010;6(23):242-7.

14. Stefanovic O, Comic L. Inhibitory effect of Cytisus nigricans L. and Cytisus capitatus scop on growth of bacteria. Afr J Microbiol Res. 2011:5:4725-30.

15. Danielle B, Lall N. Anticancer activity of certain herbs and spices on the cervical epithelial carcinoma (HeLa) cell Line. Evid Based Complement and Alternat Med. 2012;2012:1-11.

16. Moradkhani S, Kobarfard F, Ayatollahi SAM. Phytochemical investigation on chemical constituents of Achillea tenuifolia Lam. Iran J Pharm Res. 2014: 13(3):1049-54.

17. Abdullahi SM, Musa AM, Abdullahi M, Sule MI, Sani YM. Isolation of lupeol from the Stem-bark of Lonchocarpus sericeus (Papilionaceae). Scholars Acad J Biosci. 2013:1(1):18-9.

18. Jain PS, Bari SB. Isolation of lupeol, stigmasterol and campesterol from petrolium ether extract of woody stem of Whrightia tinctoria. Asian J Plant Sci. 2010;9(3):163-7.
19. Getahun T, Reneela P, Aman D. Isolation and characterization of natural products from Helinus mystachnus (Rhamnaceae). J Chem Pharm Res. 2012; 4(3):1756-62.

20. Mutai C, Bii C, Vagias C, Abatis D, Roussis V. Antimicrobial activity of Acacia mellifera extracts and lupane triterpenes. J Ethnopharmacol. 2009;123:143-8.

21. Kim KH, Choi SU, Lee KR. Bioactivity-guided isolation of cytotoxic triterpenoids from the trunk of Berberis koreana. Bioorg Med Chem Lett. 2010;20(2010):1944-7.

22. Hee KJ, Byun JC, Bandi AKR, Hyun C-G, Lee H. Compounds with elastase inhibition and free radical scavenging activities from Callistemon lanceolatus. J Med Plants Res. 2009:3(11):914-20.

23. Pan $H$, Lundgren $L N$, Anderson R. Triterpene caffeates from bark of Betula pubescens. Phytochemistry. 1994:37:795-9.

24. Eloff JN, Masoko P. The diversity of antifungal compounds of six South African Terminalia species (Combretaceae) determined by bioautography. Afr J Biotechnol. 2005;4:1425-31.

25. Ghosh P, Mandal A, Chakraborty P, Rasul MG, Chakraborty M, Saha A. Triterpenoids from Psidium guajava with Biocidal Activity. Indian J Pharm Sci. 2010;72(4):504-7. doi:10.4103/0250-474X.73936.

26. Braca A, Morelli I, Mendez J, Battinelli L, Braghiroli L, Mazzanti G. Antimicrobial Triterpenoids from Licania heteromorpha. Planta Med. 2000; 66(8):768-9. doi:10.1055/s-2000-9601.

27. Kuete $V$. Potential of Cameroonian plants and derived products against microbial infections: A review. Planta Med. 2010;76:1479-91.

28. Ndjateu FST, Tsafack RBN, Nganou BK, Awouafack MD, Wabo HK, Tene M, et al. Antimicrobial and antioxidant activities of extracts and ten compounds from three Cameroonian medicinal plants: Dissotis perkinsiae (Melastomaceae), Adenocarpus mannii (Fabaceae) and Barteria fistulosa (Passifloraceae). S Afr J Bot. 2014;91:37-42.

29. Aba OY, Ezuruike IT, Ayo RG, Habila JD, Ndukwe Gl. Isolation, antibacterial and antifungal evaluation of a-amyrenol from the root extract of Acacia ataxacantha DC. Sch Acad J Pharm. 2015;4(2):124-31.

30. Rakholiya K, Vaghela P, Rathod T, Chanda S. Comparative study of hydroalcoholic extracts of Momordica charantia L. against foodborne pathogens. Indian J Pharm Sci. 2014;76(2):148-56.

31. Burger MCM, Terezan AP, Cunha GSO, Fernandes JB, da Silva MFGF, Vieira PC, Menezes ACS. Antimicrobial activity of the myrsinoic acid A from Myrsine coriacea and the semi-synthetic derivatives. Rev Bras Farmacogn. 2015;25:451-4.

32. Santiago LA, Mayor ABR. Lupeol: An antioxidant triterpene in Ficus pseudopalma Blanco (Moraceae). Asian Pac J Trop Biomed. 2014:4(2):109-18. doi:10.1016/S2221-1691(14)60218-5.

33. Shirwaikar A, Setty MM, Bommu P, Krishnanand B. Effect of lupeol isolated from Crataeva nurvala Buch.-Ham. stem bark extract against free radical induced nephrotoxicity in rats. Indian J Exp Biol. 2004;42:686-90.

34. Wang J, Gu H-S, Pang N, Wang F-Q, Pang F, Cui H-S, et al. Alkyl Caffeates improve the antioxidant activity, antitumor property and oxidation stability of edible oil. PLoS ONE. 2014:9(4):e95909.

\section{Submit your next manuscript to BioMed Central and we will help you at every step:}

- We accept pre-submission inquiries

- Our selector tool helps you to find the most relevant journal

- We provide round the clock customer support

- Convenient online submission

- Thorough peer review

- Inclusion in PubMed and all major indexing services

- Maximum visibility for your research

Submit your manuscript at www.biomedcentral.com/submit
Biomed Central 